\title{
SPIRITUALITATEA MARAMUREŞULUI: VALENŢE ISTORICE ŞI RELIGIOS-MORALE
}

Adrian Gh. PAUL ${ }^{*}$

\section{The spirituality of Maramureş: historical and religious-moral valences}

\begin{abstract}
Spirituality defines the activity of the human spirit itself as thought, knowledge, expression, creation, life. From this point of view, spirituality can encompass a wide and diverse range of aspects of human life, i.e. any experience or manifestation of moral, religious, philosophical, literary or aesthetic nature. In this sense, we can speak of the spirituality of a nation, of a particular age, of a socio-historical group, of a region or of a person. In this report, we talk about the spirituality of the Country of Maramureş, with its specificity, richness and significance representative for the inhabitants of this Romanian land.
\end{abstract}

Key-words: spirituality, experience, Maramureş, religious aspects, historical valences

Atunci când ne referim la spiritualitatea unui popor sau a unei regiuni desigur că ne referim la tot ceea ce cuprinde spiritul, la fiinţa şi manifestările lui. Căci spiritualitatea defineşte însăşi activitatea spiritului uman ca gândire, cunoaştere, exprimare, creaţie, etc. Din acest punct de vedere, spiritualitatea poate cuprinde în sine o gamă largă şi diversă de aspecte ale vieţii umane, şi anume orice experienţă sau manifestare de ordin moral, religios, filosofic, literar ori estetic. În această accepţiune, putem vorbi de spiritualitatea unui neam, a unei epoci anume, a unui grup socio-istoric, a unei regiuni ori a unei persoane.

Desigur că privită într-un înţeles mai restrâns, forma cea mai profundă şi fundamentală până la urmă este spiritualitatea religioasă, bine ştiind că religia este înţeleasă drept legătura vie şi personală între om şi Dumnezeu sau ca şi complexitate de relaţii vii între spiritul uman şi realitatea spirituală divină $\breve{1}^{1}$. Din punct de vedere creştin, spiritualitatea se prezintă drept împlinirea aspiraţiilor fundamentale ale spiritului uman după o comuniune multiplă şi infinită şi după o realizare de sine integrală, care implică desigur raportul omului cu Dumnezeu şi cu lumea creată, unde omul se defineşte pe sine ca fiinţă care uneşte în sine spiritualul cu materialul. Din acest punct de

\footnotetext{
${ }^{*}$ Conf. univ. dr., Facultatea de Litere, Universitatea Tehnică Cluj-Napoca, str. Victoriei, nr. 76, Baia Mare (pr.adrianpaul@gmail.com).

${ }^{1}$ P.F. Daniel, Teologie şi spiritualitate, Edit. Basilica a Patriarhiei Române, Bucureşti, 2009, p. 51.
} 
vedere, spiritualitatea presupune o continuă înaintare (epectasis) şi progres în comuniunea infinită cu Dumnezeu, urcând neîntrerupt, treaptă cu treaptă, până la contemplarea lui Dumnezeu. De aceea, de pildă, pentru Sfântul Nicodim Aghioritul, creştinul se angajează într-un „război nevăzut”

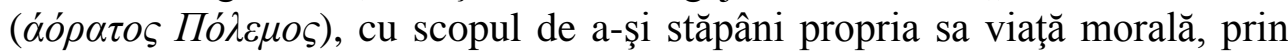
discernământ şi liniştire (isihie), punându-şi într-un anume fel ordine în existenţă, urcând pe treptele vieţii spirituale sau ale progresului spre sfinţire ${ }^{2}$. Aşadar, spiritualitatea creştină e înţeleasă drept transformarea progresivă a sufletului şi a trupului uman şi introducerea acestor elemente naturale în sfera Duhului, adică în sfinţirea sau înduhovnicirea lor. Aceasta este cu adevărat o împlinire a umanului. Cum o regăsim concret în viaţa şi preocupările omului din ţinutul voievodal al Maramureşului românesc?

Când vorbim despre spiritualitatea Maramureşului, acest ţinut binecuvântat al Ţării Maramureşului ${ }^{3}$, cu oameni frumoşi şi harnici, acest plai voievodal de la nordul ţării, care prin viaţa, cultura şi religiozitatea lui este o ramură vie a poporului român, spunem că este locul mirific ce face parte integrantă din acele zone ale culturii şi spiritualităţii româneşti a cărei istorie este determinată de conjuncturi în deplină concordanţă cu istoria pământului românesc al Transilvaniei ${ }^{4}$, atestat documentar la începutul secolului al XI-lea sub numele de „terra Ultrasilvana” (ţara de dincolo de păduri) ${ }^{5}$. Este plaiul binecuvântat al Ţării Româneşti, unde tradiţiile,

\footnotetext{
${ }^{2}$ Pr. prof. dr. Ion Bria, Dicţionar de Teologie Ortodoxă, Edit. IBM al BOR, Bucureşti, 1994, p. 364. Părintele academician Dumitru Stăniloae vorbeşte despre trei astfel de trepte spre sfinţenie: curăţirea de patimi şi câştigarea virtuţilor creştine, contemplarea raţiunilor divine ale lucrurilor şi unirea nemijlocită sau experierea imediată a lui Dumnezeu. (Pr. prof. dr. Dumitru Stăniloae, Spiritualitatea ortodoxă. Ascetica şi mistica, Edit. IBM a BOR, Bucureşti, 1992, tipărită cu binecuvântarea P.F. Părinte Patriarh Teoctist).

3 În limba dacică termenul mariş, din care îl avem pe Mureş, a avut sensul de apă, râu, iar cuvântul comun mara, provenit tot din limba dacică, a însemnat mare, extins. Astfel, din alcătuirea acestor două cuvinte s-a format hidronimul Maramureş. Este, deci, un nume compus: mara $=$ mare + mureş = râu, apă, adică râu mare. Maramureş = Râul Mare. Or, noi ştim că în această zonă curge râul mare al Tisei, iar ţinutul Maramureşului este de-a lungul Tisei superioare. Este râu mare, întrucât din dreapta Tisei, râuri precum Tarasul, Talaborul şi Neagul, iar din stânga Tisei, Vişeul, Iza cu Mara şi Săpânţa, toate se varsă în Râul Mare (Maramureş) Tisa superioară -cel mai mare râu din acest ţinut. De aici avem toponimul Ţara Maramureşului sau Terra Maramorusiensis aşa cum îl regăsim în documentele vechi. (Vezi pe larg Prof. Nuţu Roşca, Onomastica din valea Izei, Edit. Societăţii Culturale Pro Maramureş „Dragoş Vodă”, Cluj-Napoca, 2004, pp. 45-62; Idem, Istoria Bisericii Ortodoxe Române din Maramureş, Edit. Episcopiei Ortodoxe Române a Maramureşului şi Sătmarului, Baia Mare, 2015, p. 46). Tot aşa şi-au luat numele de la râuri cunoscute şi alte „țări”, precum: de la Lăpuş, Țara Lăpuşului; de la Moldova, Ţara Moldovei; de la Bârsa, avem Ţara Bârsei, ş.a.

${ }^{4}$ Vasile Pârvan, Inceputurile vieţii romane la gurile Dunării, 1923, p. 17.

${ }^{5}$ Cf. Ştefan Olteanu, Sociatatea românească la cumpăna de milenii contopite (secolele VIIXI), Bucureşti, 1983, p. 33. Precizăm că la venirea ungurilor, undeva în jurul anului 900 d.Hr., ţinutul Transilvaniei sau "voievodatul" care se întindea între Mureş, Someş, Porţile
} 
obiceiurile, folclorul, arta populară românească, graiul dulce, credinţa străbună, cultura vastă şi spiritualitatea unică se întrepătrund în mod armonios în perfecţiunea şi spiritul brav al maramureşeanului credincios, de rit ortodox, înzestrat cu atâtea şi atâtea calităţi duhovniceşti sau virtuţi, încât parcă ne este şi greu să le enumerăm. Dar toate aceste calităţi intrinseci, în special portul şi cântecul popular, bisericile de lemn, cerga şi poarta ornamentată maramureşeană, obiceiurile de nuntă, de la înmormântare sau de la marile sărbători din cursul anului bisericesc, cântecul şi hora satului, cimitirul vesel de la Săpânţa, Biserica veche şi Codicele de la Ieud, bisericile-catedrale de lemn arhicunoscute, cetera, zongura, costumele populare şi cântecul moroşenesc, toate la un loc definesc specificul maramureşean şi caracterizează spiritualitatea românească a Maramureşului, ceea ce face ca ţinutul sublim al Maramureşului şi oamenii care vieţuiesc în el să fie mult stimat în România şi deosebit de apreciat în Europa şi-ntreaga lume.

În viaţa, elanul, ţinta şi destinul său prin curgerea vremilor în istorie, specificul maramureşeanului a fost, este şi rămâne, sperăm noi în veac, conservarea şi valorificarea etnos-ului, păstrarea cu fermitate a limbii române, a valorilor autentice culturale şi spirituale, curăţia sufletului, devotamentul faţă de biserica ortodoxă şi tradiţiile străbune, precum şi obiceiurile satului şi mărturisirea credinţei neţărmurite şi nestrămutate în Dumnezeu. Născut de veacuri pe plaiurile Maramureşului voievodal, în calitatea lui de urmaş al vechilor daci liberi ${ }^{6}$, orice „moroşan”7 are datoria

Mureşului, în cetatea Biharea (in castrum Byhor), în cetatea Sătmar (castrum Zotmar) şi până la vest spre Tisa, era locuit de o populaţie vlahă (română) sub conduceea "ducelui" Menumorut. Această populaţie băştinaşă, alcătuită din slavi, bulgari şi români (vlahi), erau socotiţi descendenţi direcţi ai romanilor, vlahii ("blachi”) fiind denumiţi "blachi ac pastores Romanorum", adică "păstorii romanilor". (A se vedea Cronica lui Anonymus, în trad. rom. de G. Popa-Lisseanu, Izvoarele istoriei românilor, vol. I, Bucureşti, 1934, pp. 90-97).

${ }^{6}$ Că Maramureşul este o ţară a dacilor o dovedesc documentele vechi care consemnează că aici, pe aceste tărâmuri, nu numai că nu au pătruns romanii, ci că aici s-au refugiat daci din partea Daciei ocupată de romani. Acest fapt îl consemnează Academia Română în tratatul despre Istoria românilor, care spune: „În timpul şi la sfârşitul războaielor un număr de persoane s-au refugiat din regiunile ocupate de romani în teritoriile rămase în stăpânirea dacilor" (Vezi Academia Română, Istoria Românilor, vol. II, Edit. Enciclopedică, Bucureşti, 2001, p. 404). Acest lucru este întărit şi de alţi istorici care ţin să precizeze: „,Nu toţi dacii şi-au plecat capul sub scuturile romane. Cei care preţuiau libertatea şi nu inţ̧elegeau să poarte jug, s-au retras în această ţară a Maramureşului, pe culmile Carpaţilor Orientali, până în valea Nistrului, amestecându-se cu neamul liber al carpilor...”. (G.G. Rafiroiu, Mănăstirea Peri, Chiriaşii Tipografiei Româneşti, Oradea, 1934 , p. 8). Poate pentru aceasta istoricul Nicolae Iorga ţinea să sublinieze: „...numele Maramureş vine din moştenirea noastră dacă". (Cf. N. Iorga, Maramureşul nostru. Conferinţă ţinută la radio (difuzată la 21 decembrie 1938), editată apoi şi-n „Datina Românească", Vălenii de Munte, 1939, p. 5). 
de a gândi, trăi şi acţiona în spiritul moşilor şi strămoşilor lui maramureşeni, care prin viaţa şi faptele lor au fost o ramură vie şi parte integrantă a poporului român. Şi vorbim aici de Maramureşul voievodal, întrucât „voievodatul" era forma specifică de organizare politico-administrativă ce vor imprima în teritoriile Ţărilor Româneşti din secolele XIII-XVII, şi cu precădere în Transilvania, o dezvoltare deosebită de cotropitori sau invadatori. Organizaţia voievodală maramureşeană este de origine slavoromână, în fruntea căreia se afla un voievod, deci identică în structura ei cu cea specific românească din ţările surori Muntenia şi Moldova ${ }^{8}$, şi era recunoscut sub denumirea de „voivoda Blachorum Maramorosiensi"9 (voievodatul valah al Maramureşului) ${ }^{10}$. În acest voievodat a trăit întotdeauna o ţărănime liberă, o populaţie aparte, care se conducea după vechiul „obicei al pământului” (jus Valachorum).

Desigur, cel mai cunoscut voievod român din acest ţinut îl regăsim pe la mijlocul secolului al XIV-lea, în persoana lui Dragoş din Maramureş, ceşi avea reşedinţa voievodală în cetatea Baia ${ }^{11}$. Alături de el este voievodul Bogdan din Cuhea, care pe la anul 1359 a trecut în Moldova unde, cu sprijinul populaţiei locale, nemulţumită de dominaţia reprezentanţilor regilor Ungariei, a alungat pe fiii şi urmaşii lui Dragoş, pe nume Sas-Vodă, Balc şi Drag, punând bazele unui nou voievodat independent, al Moldovei, cu capitala la Rădăuţi, şi fiind recunoscut de moldoveni ca „voievod şi domn"12. Aşa se instalează familia voievodal-domnitoare a BogdanMuşatinilor în ţinutul est-carpatic ce cuprindea teritoriile dintre Carpaţi şi Nistru, punând bazele statului independent Moldova, locuită în acea vreme de români (vlahi), care se socoteau în afara suveranităţii coroanei ungare ce s-a impus şi domina în restul Transilvaniei. Majoritatea istoricilor recunosc că „descălecarea” lui Bogdan Vodă la răsărit de Carpaţi este o contribuţie

\footnotetext{
${ }^{7}$ Nume colectiv dat locuitorilor din Ţara Maramureşului: „După pui de moroşan/Să nu dai cu bolovan”. Potrivit etnografilor, numele „moroşan” este un apelativ înregistrat în satele moroşeneşti de pe Valea Marei sau din Săpânţa, Ieud ori Rona de Jos. Pe Valea Izei sau a Vişeului, localnicii spun „maramureşean”. (Vezi Dorin Ştef, Dicţionar de regionalisme şi arhaisme din Maramureş, Edit. Ethnologica, Baia Mare, 2015, Ediţia a II-a, revizuită, p. 249).

${ }^{8}$ Cf. Ioan Lupaş, Fazele istorice în evoluţia constituţională a Transilvaniei, Sibiu, 1944, p. 20.

9 Pr. prof. dr. Mircea Păcurariu, Istoria Bisericii româneşti din Transilvania, Banat, Crişana şi Maramureş până în 1918, Cluj-Napoca, 1992, p. 74.

${ }^{10}$ Despre acest „Voievodat” al Maramureşului se vorbea încă pe la anul 1368, după ce s-au pus bazele noului stat independent Moldova prin trecerea descălecătoare a lui Bogdan Vodă din Maramureş la est de Carpaţi. (Cf. Pr. prof. dr. Mircea Păcurariu, op. cit., p. 74).

${ }^{11}$ Marca de la Baia a fost întemeiată pe la anul 1350, ca loc strategic construit pentru a opri desele năvăliri tătare în Ardeal.

${ }^{12}$ Pr. prof. dr. Mircea Păcurariu, op. cit., p. 85.
} 
uriaşă a Maramureşului voievodal la emanciparea teritoriilor est-carpatice şi la fondarea Moldovei independente.

Ceea ce ni se pare important de subliniat este faptul că nu peste mult timp, în anul 1386, era atestată documentar şi instituţia bisericească superioară în noul stat independent Moldova, cu recunoaşterea Mitropoliei Moldovei, în fruntea căreia se afla un ierarh (mitropolit), ce oblăduia peste preoţii şi călugării ortodocşi, care aveau comunităţi cu biserici, schituri şi mănăstiri bine organizate. Această ierarhie şi aceste aşezăminte bisericeşti străvechi dovedeşte mai întâi existenţa unei vieţi bisericeşti bine organizate şi alcătuite din credincioşi ortodocşi, ce trebuiau în mod obligatoriu să aibă parohii, mănăstiri şi biserici, iar în al doilea rând această ierarhie bisericească a contribuit decisiv la păstrarea credinţei ortodoxe, şi prin ea, la apărarea identităţii de limbă şi a fiinţei naţionale româneşti, în faţa oricărei încercări de înstrăinare.

Aceste realităţi au contribuit decisiv şi la formarea unei spiritualităţi specifice zonei de interferenţă maramureşeană. Nu este întâmplător faptul că asemănător în Moldova, aici întâlnim nume de preoţi, încă din secolul al XIV-lea, precum preotul Miroslav din Giuleşti, în 1364, preotul Balotă din Apşa de Mijloc, în 1415, sau preotul Costea din Văleni, tot în $1415^{13}$. În chip firesc se pune întrebarea: cine a hirotonit pe aceşti preoţi sau cum au fost călugăriţi monahii din schiturile şi mănăstirile maramureşene dacă nu acceptăm existenţa unor ierarhi în teritoriile intracarpatice şi maramureşene chiar înaintea primelor lor atestări documentare. Prin urmare, în urma procesului de formare şi unificare teritorială sub forma de voievodat, era firesc să aibă loc şi o centralizare bisericească, în frunte cu un ierarh, care să activeze la rândul lui într-un centru episcopal sau în jurul unei mănăstiri, care să se dovedească a fi un centru de dezvoltare a culturii, limbii şi valorilor morale şi spirituale, cum şi promotoare a unei spiritualităţi autentice româneşti formată în tinda şi sub cupola Bisericii străbune.

În acest sens ţinem să precizăm că în ţinutul voievodal al Maramureşului au existat schituri şi mănăstiri, datate din prima şi a doua jumătate a secolului al XIV-lea. Aşa s-au descoperit fundaţiile unei biserici de piatră, cu fragmente de pictură murală, din a doua jumătate a secolului al XIV-lea, la Cuhea (azi Bogdan Vodă), locul de origine al voievodului Bogdan plecat în Moldova ${ }^{14}$; o biserică împodobită cu frescă în Giuleşti ${ }^{15}$, o alta în Ieud-Deal, în nordul munţilor Țibleşului, sau chiar şi Biserica Albăa, toate datate din a doua jumătate a secolul al XIV-lea. Desigur, cea mai cunoscută este şi rămâne mănăstirea Sfântul Mihail din Peri (azi Gruşevo,

\footnotetext{
${ }^{13}$ Ioan Mihali, Diplome maramureşene în secolele XIV şi XV, Sighet, 1900, p. 38, apud Pr. prof. dr. Mircea Păcurariu, op. cit., p. 91.

${ }^{14}$ Radu Popa, Ţara Maramureşului în veacul al XIV-lea, Bucureşti, 1970, p. 218.

${ }^{15}$ Idem, Cnezatul Marei, Baia Mare, 1969, p. 35.
} 
în Ucraina subcarpatică), ctitorită, se pare, de viitorul conducător al ţării Moldovei, Dragoş Vodăti

$\mathrm{Cu}$ privire la această mănăstire vom preciza pe scurt câteva detalii istoriografice. Este cunoscut faptul că după ce urmaşii lui Dragoş au fost alungaţi din Moldova de „descălecătorul” Bogdan Vodă, Baliţă şi Drag au devenit „comiţi” ai Maramureşului, Ugocei, Sătmarului, cum şi proprietarii unor sate din câteva comitate din Ungaria sud-estică şi din Transilvania. Aşa se face că descendenţi ai ctitorului mănăstirii din satul Peri, au refăcut vechea ctitorie a familiei lor, subordonându-i un teritoriu vast, de mărimea unui „principat”, din nordul Transilvaniei, pe care 1-a scos de sub jurisdicţia ierarhiei moldo-galiţiene şi a aşezat-o direct sub jurisdicţia Patriarhiei ortodoxe de Constantinopol ${ }^{17}$.

Noul protector al aşezământului, magistrul Drag, în cursul anului 1391, a plecat personal la Constantinopol cu o scrisoare semnată şi de fratele său, Baliţă, prin care cereau ca mănăstirea ctitorită de înaintaşii lor şi organizată de ei să fie declarată „stavropighie patriarhală”, adică să fie aşezată sub jurisdicţia directă a scaunului ecumenic de la Constantinopol. Aşa se face că la 13 august 1391, patriarhul ecumenic Antonie al IV-lea al Constantinopolului a semnat un ,tomos", prin care declara ctitoria dragoteştilor ,stavropighie", moment în care a şi fost investit egumenul Pahomie cu titlul de „exarh patriarhal”, adică locţiitor sau reprezentant al său cu drept de control şi judecată în probleme bisericeşti asupra preoţilor şi cu dreptul de a sfinţi biserici în ţinutul Maramureş, Sălaj, Ugocea, Ardud, Bereg şi Sătmar ${ }^{18}$. Desigur că mulţimea preoţilor şi mai ales a protopopilor atestaţi documentar în ţinutul Maramureşului pledează pentru existenţa unor ierarhi în teritoriile intracarpatice care activau fie în anumite centre eparhiale, fie pe lângă vetrele de mănăstiri recunoscute. $\mathrm{Cu}$ siguranţă că şi în jurul mănăstirii Sfântul Mihail din Peri îşi desfăşurau activitatea pastoralmisionară acei aşa-numiţii ,arhierei locali”, menţionaţi de altfel în tomos-ul

\footnotetext{
${ }^{16}$ Cf. G.F. Rafiroiu, Mănăstirea din Peri, Oradea, 1934, p. 48.

17 Arhim. Veniamin Micle, Prima tipografie în spaţiul românesc: Mănăstirea Peri din Maramureş, în volumul "Preocupări cărturăreşti", Edit. Mănăstirii Bistriţa, Eparhia Râmnicului, 2007, p. 142.

18 A se vedea tomos-ul publicat în greceşte şi latineşte la Ioan Mihali, Diplome maramureşene, p. 109-110. Precizăm că cei doi fraţi îşi asigurau dreptul de patronat bisericesc asupra credincioşilor ortodocşi români din părţile de nord ale Transilvaniei prin acest tomos primit din partea Patriarhiei ecumenice din Constantinopol. Ceea ce este şi mai important, prin acelaşi tomos se acorda celor doi fraţi dreptul de a alege un alt egumen, după moartea lui Pahomie, cum şi dreptul de a alege „locţiitor” al scaunului mitropolitan din Ţara Haliciului, care ierarh să provină din rândul monahilor de la Perii Maramureşului. (Ioan Mihali, Diplome maramureşene, p. 109-111).
} 
sinodal al Patriarhului Antonie al Constantinopolului, şi despre care se zicea că: „sfinţeau biserici, ${ }^{, 19}$.

Începuturile mănăstirii sunt legate de viaţa isihastă din această parte a ţării, specifică Ortodoxiei bizantine a secolului al XV-lea răsfrântă şi-n această parte de lume, dar şi preocuparea majoră a promovării limbii şi culturii româneşti prin tipăriturile evidenţiate prin scrieri vechi chiar în incinta mănăstirii. Este foarte cunoscut faptul că mai înainte ca Sas Vodă, împreună cu fiii săi, Drag şi Balc, să întemeieze la Peri, prima mănăstire din Maramureş, exista aici o puternică comunitate isihastă, ce avea acelaşi ocrotitor ca şi familia voievodală: Sf. Arhanghel Mihail. Voievozii Baliţă şi Drag, după modelul preluat din Țara Românească şi Moldova, s-au străduit să pună bazele unei şcoli mănăstireşti la Peri, care cu timpul a devenit o vestită şcoală mănăstirească, unde candidaţii la preoţie învăţau scrisul, cititul, catehismul, cântările bisericeşti, oficierea slujbelor şi predicarea Evangheliei. Şcoala avea un caracter slavo-român, atât în sensul însuşirii limbii slavone bisericeşti concomitent cu folosirea limbii române, cât şi în scopul traducerilor şi al copiilor de texte vechi, întrucât monahii de la Peri cunoşteau atât limba latină, limba oficială a statului maghiar, cât şi greaca şi slavona, chiar şi slavona în dialect ucrainian. (A se vedea manuscrisul de la Ieud). Acest lucru a făcut ca ritul bizantin de limbă slavă să devină pentru românii din Transilvania, şi cu precădere din Maramureş, în împrejurările de atunci, un mijloc de apărare şi de conservare a Ortodoxiei. Prin „ritul bizantino-slav" românii maramureşeni şi-au putut menţine nu doar credinţa ortodoxă, ci şi naţionalitatea, căci o eventuală trecere la ritul apusean folosit din secolul al XI-lea de Biserica maghiară în Transilvania- ar fi dus iniţial la „catolicizarea” lor, iar cu timpul la deznaţionalizare, mai precis la maghiarizare $^{20}$. Or, prin introducerea ritului bizantin de limbă slavă, românii-moroşeni au rămas şi pe mai departe sub jurisdicţia Patriarhiei Ortodoxe de Constantinopol, rămânând până astăzi singurul popor de limbă şi origine romanică de rit ortodox, deci legaţi de Roma prin limbă - limba „protoromână” sau „străromână” fiind o limbă neolatină - iar de Constantinopol prin credinţa ortodoxă $\breve{a}^{21}$.

\footnotetext{
${ }^{19}$ A se vedea pe larg P.S. Damaschin Coravu Severineanul, Mănăstirea din Peri şi importanţa sa istorică, în „Mitropolia Olteniei”, an. XXXIV, Nr. 7-9 / 1982, pp. 496-514.

${ }^{20}$ Acest lucru îl dovedeşte consemnarea făcută de istoricul Alexandru Filipaşcu care ţine să precizeze: „Unirea cu calvinii a fost o monstruozitate lipsită de cea mai elementară logică, care deodată cu calvinizarea, ar fi adus cu sine şi o repentină maghiarizare a întregului popor român din Maramureş". (Cf. Alexandru Filipaşcu, Istoria Maramureşului, Tipografia Ziarului „Universul”, Bucureşti, 1940, p. 21).

${ }^{21}$ Milan Şesan, Tradiţiile chirilometodiene, în „Mitropolia Ardealului”, an. IV, Nr. 13/1962, pp. 64. (Detalii despre introducerea ,ritului bizantino-slav” în Biserica românească a se vedea P.P. Panaitescu, Introducere în istoria culturii româneşti, Bucureşti, 1969, pp. 118-122 şi pp. 185-201).
} 
Prin urmare, asemănător activităţilor cărturăreşti din celelalte Mitropolii româneşti moldovene şi ungrovlahe, la mănăstirea maramureşeană Peri s-a pus bazele unei activităţi culturale de mare însemnătate prin iniţiativa de scriere de cărţi în limba slavonă, cum şi copierea de cărţi de cult din slavona bisericească în limba română. Această atitudine aplecată spre activităţi cărturăreşti a dat naştere la formarea unei spiritualităţi puternice, de sorginte divină, pe filieră bizantină. Nu mai vorbim despre adoptarea slavonei ca limbă de cult, care a oferit românilor maramureşeni accesul la toate creaţiile culturale ale Bizanţului, recunoscut drept cel mai strălucit centru de cultură al Evului mediu european până la Renaştere, cu accesul la scrierile patristice ale Sfinţilor Părinţi răsăriteni, care au fost şi au reprezentat de-a lungul secolelor un tezaur format din opere teologice, aghiografice, omiletice, imnografice, istorice, filosofice, juridice şi beletristice, create sau vehiculate de cultura bizantină. Apoi, formarea unei culturi populare prin numeroasele creaţii folclorice şi populare orale, în limba română, care au stat la baza culturii scrise româneşti de mai târziu 22 . Şi este binecunoscută universalitatea portului popular, a cântecului şi folclorului, al datinilor strămoşeşti şi al tradiţiilor maramureşeneşti, care sunt un tezaur de nestemate în constelaţia etnos-ului şi a culturii populare româneşti. Aşa se face că Biserica maramureşeană sau spiritul sacru din jurul mănăstirilor şi a bisericilor vechi a cultivat frumosul prin toate mijloacele de care a dispus, întrucât credinţa creştină, primită din Răsărit, nu este altceva decât cea mai profundă poezie a sufletului românesc întâlnit în orice manifestare culturală, de spiritualitate sau de etnos în rândul maramureşenilor.

Prin urmare, odată cu copierea cărţilor sfinte din limba slavonă în limba română, practicarea ritului bizantin la slujbele bisericeşti şi mai ales folosirea limbii române în viaţa de cult prin cuvântări omiletice sau prin propovăduirea cuvântului Evangheliei, al Apostolului, al Tetraevangheliarelor, al Omiliilor şi tuturor scrierilor vechi copiate şi traduse, toate păstrate în manuscrise, dovedesc preocuparea majoră a monahilor, ierarhilor şi cărturarilor maramureşeni în vederea formării şi dezvoltării limbii româneşti în viu grai maramureşean şi în tonul dat de ortodoxia românească, acest „acoperiş de azur al sufletului românesc de totdeauna"23. Credinţa străbună, graiul dulce românesc, tradiţia vie şi slujba bizantină a bisericii sunt valorile nepieritoare care 1-au învăluit dintotdeauna pe „moroşan”. Iată un cântec popular din Maramureş care conferă imense satisfacţii sufleteşti maramureşeanului tradiţionalist:

\footnotetext{
${ }^{22}$ A se vedea Istoria literaturii române, vol. I, Edit. Academiei Române, Bucureşti, 1964, pp. 11-229.

${ }^{23}$ Cum o numeşte Prof. Ion A. Popescu, apud Viorel Thira, Spiritualitatea maramureşeană. Câteva insemnări, în volumul "Maramureş -vatră de istorie milenarăa", Edit. Dragoş Vodă, Cluj-Napoca, 1997, p. 290.
} 


\section{„Lege mai atrăgătoare \\ De cât legea românească \\ Cât e lumea şi pământul \\ Nu mai cred să se găsească! \\ Limba cu credinţa noastră \\ Se topesc in armonie \\ La vecernii, la utrenii \\ Şi la Sfânta Liturghie... \\ Iară slujba-nmormântării \\ E-ntocmită de minune; \\ Afli-ntrânsa mângâiere \\ Şi adâncă-nţelepciune" 24 .}

Toţi istoricii şi istoriografii recunosc faptul că odată cu venirea egumenului Pahomie în ţinutul Maramureşului, a înfiinţat la Peri o şcoală de caligrafi, unde s-au tradus pentru prima dată în limba română Psaltirea, Faptele Apostolilor şi Evanghelia. Mai este cunoscut şi faptul că de la Peri se păstrează cel mai vechi text în limba română, „Legenda Duminicii“", datat în anul 1391, regăsit în Manuscrisul de la $\operatorname{Ieud}^{25}$. Cu timpul, aici a funcţionat şi o tipografie, unde s-au tipărit o serie de cărţi religioase. Mai mult, la Peri, s-a instalat şi centrul episcopal al Maramureşului, unde şi-au avut reşedinţa mai mulţi ierarhi într-un interval de 315 ani, printre care şi Sfântul Ierarh Iosif Mărturisitorul din Maramureş ${ }^{26}$.

Să nu uităm de cel mai valoros patrimoniu natural-religios din Maramureş: bisericile de lemn reprezentative, care sunt adevărate catedrale vii ale sufletului oricărui moroşan, capodopere mari ale creaţiei arhitecturii universale ce creează prin dimensiunea înălţimilor lor o strânsă legătură între cer şi pământ, ajutându-ne să înţelegem împlinirea voii lui Dumnezeu în viaţa noastră de aici, şi care este în competiţie şi mereu îndreptată spre eternitate. Bisericile de lemn reprezentative din Maramureş par nişte făclii ridicate spre ceruri, gata întotdeauna să aprindă şi să ardă, fără să mistuie,

\footnotetext{
${ }^{24}$ Gh. Băltean, poezia Legea noastră din volumul „Pâinea cerească”.

${ }^{25}$ Codicele a fost găsit de preotul Artemie Anderco din Ieud şi oferit preşedintelui Astrei, Andrei Bârseanu, care 1-a dus la Academia Română din Bucureşti, în noiembrie 1921. A se vedea editarea Manuscrisului de la Ieud, cu comentarii şi aprecieri oportune, la Prof. dr. Nuţu Roşca, Manuscrisul de la Ieud, document apărut cu binecuvântarea Î.P.S. Arhiepiscop Justinian Chira al Maramureşului, la Edit. Universităţii de Nord, Baia Mare, 2011.

26 Arhipăstor între anii 1690-1711, decretat şi canonizat „sfânt” de Biserica Ortodoxă Română, potrivit Actului Sinodal din 20 iunie 2992, cu prăznuirea lui la 24 aprilie şi recunoscut: Sfântul Ierarh Iosif Mărturisitorul din Maramureş. (A se vedea Actul Sinodal la Pr. dr. Vasile Augustin, Episcopia Maramureşului: organizarea administrativă, Edit. Universităţii de Nord, Baia Mare, 2006, p. 297-298).
} 
luminând şi încălzind inimile celor ce le cercetează şi le preţuiesc ca pe adevărate „moaşte” de sfinţi. Ele sunt podoaba cea mai de preţ a poporului din Maramureş -capodopere falnice pline de tămâia rugăciunii; mărturia vie a credinţei adevărate şi a vredniciei poporului din acest ţinut binecuvântat de Dumnezeu; dovada hărniciei moroşanului îmbinată parcă perfect în armonia simţului estetic, potrivit aşezării sale sufleteşti, cu echilibrul elegant al formelor şi supleţea liniilor ce se înalţă falnic spre cer, ceea ce fac cinste geniului creator românesc. $\mathrm{Nu}$ este de mirare pentru nimeni că datorită importanţei şi frumuseţii lor, unele dintre bisericii de lemn maramureşene (şapte la număr) au intrat în rândul valorilor patrimoniului cultural universal, alături de marile capodopere ale Renaşterii şi Antichităţii, fiind integrate de drept în Patrimoniul UNESCO.

Putem să numim aşadar Maramureşul ţinut de legendă şi vis, de istorie şi fapte măreţe, cu oameni harnici şi făloşi; regiune românească bogată spiritual şi valoric, unde fiecare ,pui de moroşan” născut face să perpetueze viţa nobilă a voievozilor ce au obârşia la strămoşii daci.

\section{Bibliografie}

AUGUSTIN, Pr. dr. Vasile, Episcopia Maramureşului: organizarea administrativă, Edit. Universităţii de Nord, Baia Mare, 2006

BRIA, Pr. prof. dr. Ion, Dicţionar de Teologie Ortodoxă, Editura IBM al BOR, Bucureşti, 1994

DANIEL, P.F., Teologie şi spiritualitate, Editura Basilica a Patriarhiei Române, Bucureşti, 2009

DAMASCHIN, P.S. Coravu Severineanul, Mănăstirea din Peri şi importanţa sa istorică, în „Mitropolia Olteniei”, an. XXXIV, Nr. 7-9/ 1982

FILIPAŞCU, Alexandru, Istoria Maramureşului, Tipografia Ziarului „Universul”, Bucureşti, 1940

IORGA, Nicolae, Maramureşul nostru. Conferinţă ţinută la radio (difuzată la 21 decembrie 1938), editată apoi şi-n „Datina Românească”, Vălenii de Munte, 1939

Istoria literaturii române, vol. I, Editura Academiei Române, Bucureşti, 1964

Istoria Românilor, vol. II, Editura Enciclopedică, Bucureşti, 2001

LUPAŞ, Ioan, Fazele istorice în evoluţia constituţională a Transilvaniei, Sibiu, 1944

MICLE, Arhim. Veniamin, Prima tipografie în spaţiul românesc: Mănăstirea Peri din Maramureş, în volumul "Preocupări cărturăreşti", Editura Mănăstirii Bistriţa, Eparhia Râmnicului, 2007

OLTEANU Ştefan, Societatea românească la cumpăna de milenii contopite (secolele VII-XI), Bucureşti, 1983 
PANAITESCU, P.P., Introducere în istoria culturii româneşti, Bucureşti, 1969

PÂRVAN, Vasile, Începuturile vieţii romane la gurile Dunării, 1923

PĂCURARIU, Pr. prof. dr. Mircea, Istoria Bisericii româneşti din Transilvania, Banat, Crişana şi Maramureş până în 1918, Cluj-Napoca, 1992

POPA, Radu, Ţara Maramureşului în veacul al XIV-lea, Bucureşti, 1970

Idem, Cnezatul Marei, Baia Mare, 1969

RAFIROIU, G.G., Mănăstirea Peri, Chiriaşii Tipografiei Româneşti, Oradea, 1934

ROŞCA, Prof. Nuţu, Onomastica din valea Izei, Editura Societăţii Culturale Pro Maramureș „Dragoș Vodă”, Cluj-Napoca, 2004

Idem, Istoria Bisericii Ortodoxe Române din Maramureş, Editura Episcopiei Ortodoxe Române a Maramureşului şi Sătmarului, Baia Mare, 2015

Idem, Manuscrisul de la Ieud, document apărut cu binecuvântarea Î.P.S. Arhiepiscop Justinian Chira al Maramureşului, la Editura Universităţii de Nord, Baia Mare, 2011

STĂNILOAE, Pr. prof. dr. Dumitru, Spiritualitatea ortodoxă. Ascetica şi mistica, Editura IBM a BOR, Bucureşti, 1992

ŞTEF, Dorin, Dicţionar de regionalisme şi arhaisme din Maramureş, Editura Ethnologica, Baia Mare, 2015, Ediţia a II-a, revizuită

ŞESAN, Milan, Tradiţille chirilometodiene, în „Mitropolia Ardealului”, an. IV, Nr. $1-3 / 1962$

THIRA, Viorel, Spiritualitatea maramureşeană. Câteva însemnări, în volumul "Maramureş -vatră de istorie milenară", Editura Dragoş Vodă, ClujNapoca, 1997 